\section{Karnatak University}

Dr. B. H. Nagoor, Coordinator, Dr. D. C. Pavate Foundation, C/o Department of Economics, Karnatak University, Dharwad, Karnataka 580003, India

Email: nagoor_bh@yahoo.co.in

\section{Dr. D. C. Pavate Memorial Visiting Fellowship}

Subjects: Three fellowships are offered under different faculties for a total period of four months from January each year. The fellowships will include economy class return airfare, a stipend of 3500 pounds and the appropriate academic fees Eligibility: To apply for the D. C. Pavate Memorial Visiting Fellowship, candidates must meet the following criteria: 1 . Be below the age of 40 years as on January 1 of the academic year. 2. Secured a $\mathrm{PhD}$ or a masters degree or equivalent with a minimum of first class. 3. For fellowships valid for Karnataka candidates: A Karnataka candidate is any person who has studied at an educational institution in Karnataka or been employed in Karnataka for a minimum of 5 years continuously

Level of Study: Graduate

Type: Fellowship

Valu: $£ 3,500$

Frequency: 3 times each year

Country of Study: Any country

Application Procedure: Application forms can be downloaded at www.kud.ac.in

Closing Date: 10 July

Funding: Private

\section{Kay Kendall Leukaemia Fund}

\section{Kay Kendall Leukaemia Fund Junior and Intermediate Research Fellowships}

The Kay Kendall Leukaemia Fund, The Peak 5 Wilton Road, SW1V 1AN, London, United Kingdom

Tel: $\quad$ (44) 2074100330

Email: info@kklf.org.uk

Contact: Mrs H McLeod, Fund Executive

Subjects: Intermediate fellowships are awarded annually to scientists of outstanding potential allowing them to gain experience in an international centre of excellence prior to establishing an independent research group of their own. Applicants may be of any nationality and should be based currently in the United Kingdom and/or be planning to work in a recognised university or other equivalent department in a United Kingdom institution. A significant proportion of the fellowship (up to 3 years) may be spent in an appropriate institution outside the United Kingdom where this can be clearly demonstrated to be of significant benefit. The fellowship will cover the cost of the fellow's salary and may support one assistant together with consumable support in the United Kingdom, and travel costs where appropriate. Up to three junior fellowships are awarded annually and cover salary costs for three years and costs of laboratory consumables in the United Kingdom and travel costs where appropriate. They are made in the following categories: 1 . Scientific fellowships - open to scientists who will usually have 1-4 years' postdoctoral experience and be intending either to work at 
a recognised United Kingdom research institution or seeking a travel fellowship for relevant work abroad, with funding and administration via an appropriate United Kingdom institution. 2. Clinical research fellow - open to clinicians seeking funding for a $\mathrm{PhD}$ in the field of leukaemia research, usually at a United Kingdom centre

Purpose: Scientific Research and Clinical Research Fellowships on aspects of leukaemia and related haematological malignancies

Eligibility: Intermediate - Non-medical applicants will already have completed their $\mathrm{PhD}$ and will usually have 3-8 years of post-doctoral research experience. For medical graduates the Intermediate Fellowship is suitable for individuals who have obtained a $\mathrm{PhD}$; in exceptional cases completion of clinical training during an Intermediate Fellowship may also be possible. Applicants for the Intermediate Fellowship will be expected to demonstrate their potential for achieving international status as researchers in leukaemia or a closely related field. Junior - Non-medical scientists who will usually have 1-4 years' postdoctoral experience and are intending to work either at a recognised United Kingdom research institution or seeking a travel fellowship for relevant work abroad may apply for a scientific fellowship, with funding and administration via an appropriate United Kingdom institution. Clinicians seeking funding for a $\mathrm{PhD}$ in the field of leukaemia research, usually at a United Kingdom centre, may apply for a clinical research fellowship

Level of Study: Postgraduate

Type: A variable number of fellowships

Value: Fellow's salary and consumable costs. Intermediate fellowships may include RA salary costs and Family Allowance if time is taken abroad

Length of Study: Junior - 3 years; Intermediate - 4 years

Frequency: Annual

Study Establishment: United Kingdom university or research institution, or equivalent abroad (but to be administered by a United Kingdom university or research institution) Country of Study: United Kingdom

Application Procedure: Calls for applications and relevant deadlines are advertised in the spring for Intermediate Fellowships and the summer for Junior Fellowships. Application is by application form available from KKLF. It must include a completed application form with all signatures, a scientific proposal, and a statement from the Departmental Chairman or Laboratory Director that he/she is prepared to make available all appropriate facilities if the applicant is successful. In addition it should include references, costings, and CV. Applications are triaged post-deadline to determine which will be sent out to review

Closing Date: as advertised on website and see applications procedure above

Funding: Trusts

No. of awards offered last year: IF - 2: JF - 3

\section{Keele University}

Keele, ST5 5BG, Staffordshire, United Kingdom

Tel: (44) 1782584002

Fax: (44) 1782632343

Email: aaa12@keele.ac.uk

Website: www.keele.ac.uk

Contact: Ms Joan Scrivener, Postgraduate Admissions Officer

Keele University is committed to provide high quality teaching and research, with particular emphasis on multidisciplinary and interdisciplinary studies, which are seen to be in the forefront of developments worldwide, promote networking, partnership and collaboration between disciplines and organisations at regional, national and international level, and develop the estate as a leading exemplar of a learning and working campus community of students, staff and business.

\section{Keele MBA Programme}

Length of Study: 1 year full-time and 2 years part-time Application Procedure: Applicants must complete an application form

Closing Date: 31 July for full-time course and 31 December or 31 July for the part-time course

\section{For further information contact:}

Tel: (44) 1782583425

Fax: (44) 1782584272

Email: mna09@keele.ac.uk

Contact: Ms Linda Bromage, MBA Programmes Manager

\section{Keio University}

Garduate School of Business Administration, 2-1-1 Hiyoshi Honcho, Kohoku-ku, Yokohama 223-8523, Japan

Tel: $\quad$ (81) 939624436

Contact: MBA Admissions Officer

Keio University is the first private university in Japan, founded in 1858 by Yukichi Fukuzawa, who is often called the intellectual father of modern Japan. Since then Keio University has developed a brilliant history of producing distinguished personalities in every field of society. 


\section{Joint Japan World Bank Graduate Scholarship Program}

Purpose: The Joint Japan/World Bank Graduate Scholarship Program (JJ/WBGSP) is open to women and men from developing countries with relevant professional experience and a history of supporting their countries' development efforts who are applying to a master degree program in a development-related topic

Eligibility: The applicant must meet the following eligibility criteria: 1 . Be a national of a World Bank member developing country (see above). 2. Not hold dual citizenship of a developed country. 3. Be in good health. 4. Hold a Bachelor (or equivalent) degree earned at least 3 years prior to the Application Deadline date. 5. Have 3 years or more of recent development-related experience after earning a Bachelor (or equivalent) degree. 6. Be employed in development-related work in a paid full- time position at the time of submitting the scholarship application. The only exception to this criterion is for developing country nationals from a country that will be on the updated list of Fragile and Conflict States provided to applicants in the Application Guidelines for each call for scholarships. 7. On or before the Scholarship Application Deadline date, be admitted unconditionally (except for funding) for the upcoming academic year to at least one of the JJ/WBGSP preferred university master's programs and located outside of the applicant's country of citizenship and country of residence listed at the time the call for scholarship applications open

Level of Study: Postgraduate

Type: Scholarship

Length of Study: 2 years

Frequency: Annual

Country of Study: Any country

Application Procedure: For scholarships to one of the preferred master's programs, you must first apply and be unconditionally accepted for admissions to one or more of the Preferred Program(s) to be considered for a JJ/WBGSP scholarship. The call for applications is open from 7 March to 11 April. For scholarships to one of the partner master's programs, you must apply for admission to one or more of the Partner Masters Degree Program(s). After reviewing submitted applications, each Partner Master Degree Program will identify a short list of eligible candidates who will then be invited by the JJ/WBGSP Secretariat to apply for a JJ/WBGSP scholarship

Closing Date: 11 April

Funding: Private

Additional Information: For further information, check the below website. www.ic.keio.ac.jp/en/study/jjwbgsp/ index.htm

\section{For further information contact:}

Email: ic-scholarship@adst.keio.ac.jp

\section{Kennan Institute}

Woodrow Wilson International Center for Scholars, One Woodrow Wilson Plaza, 1300 Pennsylvania Avenue North West, Washington, DC 20004 3027, United States of America
Tel:
(1) 2026914100
Fax: (1) 2026914247
Email: kennan@wilsoncenter.org
Website: www.wilsoncenter.org
Contact: Scholar Programs

The Kennan Institute for Advanced Russian Studies sponsors advanced research on the successor states to the USSR and encourages Eurasian studies with its public lecture and publication programmes, maintaining contact with scholars and research centres abroad. The Institute seeks to function as a forum where the scholarly community can interact with public policymakers.

\section{Title VIII-Supported Summer Research Grant}

Subjects: Eurasian studies in the social sciences and humanities

Purpose: To support United States citizens whose research in the social sciences or humanities focuses on the former Soviet Union, and who demonstrate a particular need to use the resources of the Washington, DC area

Eligibility: Open to academic participants with a doctoral degree or those who have nearly completed their dissertation. For non-academic participants, an equivalent level of professional development is required. Applicants must be United States citizens

Level of Study: Doctorate, Postdoctorate, Postgraduate, Predoctorate, Professional development, Research

Type: Scholarship

Value: US\$6,400. The Kennan Institute provides a work space and research assistant for each Summer Scholar. Travel and accommodation expenses are not directly covered by this grant Length of Study: Up to 62 days

Frequency: Dependent on funds available

Study Establishment: The Kennan Institute

Country of Study: United States of America

No. of awards offered: 25

Application Procedure: Applicants must submit a concise description of their research project of 700-800 words, a curriculum vitae, a statement of preferred dates of residence in Washington, DC, and two letters of recommendation specifically in support of the research proposal. No application form required 
Closing Date: 15 January

Funding: Government

No. of awards offered last year: 2

No. of awards applicants last year: 25

Additional Information: Please email kennan@wil soncenter.org or see our website with further details www. wilsoncenter.org/opportunity/kennan-institute-summer-resea rch-scholarships

\section{For further information contact:}

Email: outbound@americancouncils.org

\section{Kennedy Memorial Trust}

3 Birdcage Walk, Westminster, SW1H 9JJ, London, United Kingdom

Tel: $\quad$ (44) 2072221151

Fax: (44) 2072227189

Email: annie@kennedytrust.org.uk

Website: www.kennedytrust.org.uk

Contact: Ms Annie Thomas, Secretary

As part of the British national memorial to President Kennedy, the Kennedy Memorial Trust awards scholarships to British postgraduate students for study at Harvard University or the Massachusetts Institute of Technology. The awards are offered annually following a national competition and cover tuition costs and a stipend to meet living expenses.

\section{Kennedy Scholarships}

Subjects: Kennedy Scholarships are tenable across the range of graduate programs offered at both Harvard University and the Massachusetts Institute of Technology

Purpose: Kennedy Scholarships are the United Kingdom's living memorial to President Kennedy. They are offered annually in competition to enable British citizens who are British graduates to take graduate programs at Harvard University and the Massachusetts Institute of Technology

Eligibility: Applicants must be British citizens at the time of application who are, or will be, graduates of a British university by the time of taking up the award. If not due to graduate in the year of award, applicants must have spent at least 2 of the 7 years prior to September 1st of year in which tenure will start studying as an undergraduate at a United Kingdom university

Level of Study: Doctorate, Graduate, Predoctorate, Professional development, Postgraduate (MSc)
Type: Scholarship

Value: Full tuition and health insurances fees plus a meanstested stipend for living expenses

Length of Study: Typically one full academic year, starting in the Fall

Frequency: Annual

Study Establishment: Harvard University; Massachusetts Institute of Technology

Country of Study: United States of America

No. of awards offered: 182

Application Procedure: Applications are made online and comprise a personal statement, an academic and professional history and the contact details for 2 referees who will be contacted automatically. See the website for full information Closing Date: mid- to late-October in the year prior to starting in the United States

Funding: Private

Contributor: The Kennedy Memorial Trust is a British charity, dependent upon charitable donations

No. of awards offered last year: 10

No. of awards applicants last year: 182

\section{For further information contact:}

Tel: $\quad$ (44) 2072221151

Email:_annie@kennedytrust.org.uk

Contact: Mrs Annie Thomas

\section{Kidney Health Australia}

Level 1, 25 North Terrace, GPO Box 9993, Adelaide, SA 5001, Australia

Tel: $\quad$ (61) 883347555

Fax: (61) 883347545

Email: research@kidney.org.au

Website: www.kidney.org.au

Contact: Medical Director's Office

Founded in 1968, the Australian Kidney Foundation's mission is to be recognized as the leading non-profit national organization providing funding for, and taking the initiative in, the prevention of kidney and urinary tract diseases.

\section{Australian Kidney Foundation Biomedical Scholarships}

Subjects: Medical and scientific kidney and urology-related research 
Purpose: To provide scholarships for individuals wishing to study full-time for the research degrees

Eligibility: Open to Australian applicants who are graduates, or proposing to graduate in the current academic year. Parttime students are not eligible

Level of Study: Doctorate, Postgraduate

Type: Scholarship

Value: A\$24,000 for science and A\$35,000 for medical

Length of Study: 2 or 3 years

Frequency: Annual

Country of Study: Any country

Closing Date: 31 August

Contributor: Kidney Health Australia

\section{For further information contact:}

Kidney Health Australia, GPO Box 9993, Adelaide, SA 5001, Australia

Email: research@kidney.org.au

Contact: The Medical Director

\section{Australian Kidney Foundation Medical Research Grants and Scholarships}

Subjects: The functions and disease of the kidney, urinary tract and related organs

Purpose: To support medical research

Eligibility: Open to Australian citizens who are graduates of Australian medical schools or overseas graduates who are eligible for Australian citizenship and for registration as medical practitioners in Australia

Level of Study: Doctorate, Postgraduate

Type: Scholarship

Value: Please contact the organization

Length of Study: Up to 3 years

Frequency: Annual

Study Establishment: Any approved medical centre, university or research institute

Country of Study: Australia

Application Procedure: See guidelines in website Closing Date: 31 August

Additional Information: Please see the website for further details www.kidney.org.au/HealthProfessionals/MedicalRe searchFunding/tabid/633/Default.aspx

\section{For further information contact:}

Email: research@kidney.org.au

Contact: Joanna Stoic, Medical Director's Office

\section{Investigator Driven Research Grants and Scholars}

Subjects: Multiple sclerosis research

Purpose: To award investigators who have applied to the NHMRC for funding but have just missed the cut-off mark Eligibility: Open to projects that are ranked as worthy of funding

Type: Scholarship

Frequency: Annual

Country of Study: Any country

Contributor: Kidney Health Australia

For further information contact:

Email: research@kidney.org.au

\section{Kidney Research United Kingdom}

Nene Hall, Lynch Wood Park, Cambridgeshire PE2 6FZ, Peterborough, United Kingdom

Tel:

Email: grants@kidneyresearchuk.org

Website: www.kidneyresearchuk.org

Contact: Mrs Elaine Davies, Director of Research Operations

Kidney Research United Kingdom aims to advance and promote research into kidney and renal disease. These may include epidemiological, clinical or biological approaches to relevant problems. All research must be carried out in the United Kingdom.

\section{Allied Health Professional Fellowship (clinical)}

Subjects: Renal medicine

Purpose: To enable nurses and allied health professionals to undertake a renal research study and obtain a higher degree (Masters, DPhil or PhD)

Eligibility: Open to nurses and allied health professionals to undertake a renal research study with the object of obtaining a higher degree (Masters, DPhil or PhD). Work and employment must be in the United Kingdom

Level of Study: Doctorate, Postdoctorate, Postgraduate

Value: The salary will be based on the appropriate NHS or university scale, and an allowance for consumables and higher degree fees is included

Length of Study: 3 years at full time or 5 years at part time Frequency: Annual

Country of Study: Any country 
Application Procedure: Applicants must complete an online application

Closing Date: Late November (check with website)

For further information contact:

Email: grants@kidneyresearchuk.org

\section{King's College London}

King's College London, Strand, WC2R 2LS, London, United Kingdom

Email: funding@kcl.ac.uk

\section{Bosco Tso \& Emily Ng Scholarship}

Purpose: The scholarship is intended to help support the winner with the cost of tuition fees and living expenses whilst studying Eligibility: Eligible students must be: 1 . be undertaking the 1 year LLM Law programme at King's. 2. be able to demonstrate a need for financial assistance. 3. have provided a written personal statement. 4 . be willing to provide an end of year report and a letter of thanks to the donor. There are few more conditions being implied for the scholarship. The award of a scholarship to an offer-holder will be conditional upon: 1. the offer-holder accepting a place on the King's LLM programme and 2. the fulfilment by the offer-holder of all conditions, both academic and English Language, attached to his or her offer of a place at King's by 10 July

Level of Study: Graduate, Professional development

Type: Scholarship

Value: $£ 22,500$ (European Union/International) which intended towards tuition fees and others

Frequency: Annual

Country of Study: Any country

Application Procedure: Kindly access the application form with the below link. www.kcl.ac.uk/study/assets/pdf/feesand-funding/postgraduate/bosco-tso-emily-ng-scholarship2019.pdf. The application form should be completed, scanned and emailed to funding@kcl.ac.uk. Alternatively it may be posted to Student Funding Office. You must submit a word/pdf version of your supporting statement. This should be emailed to funding@kcl.ac.uk

Closing Date: 12 April

Funding: Private

\section{For further information contact:}

King's College London, Strand, WC2R 2LS, London, United Kingdom

Email: funding@kcl.ac.uk

\section{Claire Godfrey Postgraduate Fund}

Purpose: The objective of the fund is to support postgraduate students at King's who are suffering unexpected, studyrelated, financial hardship

Eligibility: The fund is open to all home postgraduate students in financial hardship. All applicants will have to submit documentary evidence with their applications to verify their financial status

Level of Study: Postgraduate

Type: Funding support

Frequency: Annual

Country of Study: Any country

Application Procedure: To apply, you should download the form here. www.kcl.ac.uk/study/assets/pdf/fees-and-funding/ postgraduate/claire-godfrey-postgraduate-fund.pdf. Please ensure that you read the guidance notes carefully before completing the application form and provide all the relevant supporting documentation along with the completed application form to funding@kcl.ac.uk. The deadline for receiving application forms and supporting documents is Friday 26 April. Late applications will not be considered

Closing Date: 30 April

Funding: Private

Additional Information: All applicants will be notified of the outcome of their application in May. The successful applicant will also receive payment at that time

\section{For further information contact:}

King's College London, Strand, WC2R 2LS, London, United Kingdom

Email: funding@kcl.ac.uk

\section{King's-HKU Joint PhD Scholarship}

Purpose: King's College London ranked amongst some of the world's most prestigious universities. It is the researchintensive university with a global reputation for academic discovery and teaching. King's is in the top seven United Kingdom universities for research

Eligibility: 1. Be due to commence a full-time joint $\mathrm{PhD}$ programme run in collaboration between King's College London and the University of Hong Kong during the academic year. 2. Have applied to King's College London as the home institution. 3. Have submitted all the required application materials by the funding deadline

Level of Study: Postgraduate

Type: Scholarship

Value: $£ 1,500$

Length of Study: 4 year

Frequency: Annual 
Country of Study: Any country

Closing Date: 31 May

Funding: International office

\section{For further information contact:}

Tel: (44) 2078484568

Email: doctoralstudies@kcl.ac.uk

\section{Norman Spink Scholarship}

Subjects: Law

Purpose: The Norman Spink Scholarship Fund is a fund to help support all students who are able to demonstrate need of financial assistance, to undertake the one year LLM Law programme at King's specifically related to Tax Law

Eligibility: Eligible students must: 1. be undertaking the 1 year LLM Law programme at King's. 2. be undertaking the LLM (Tax Law Pathway). 3. be able to demonstrate a need for financial assistance. 4 . have provided a written personal statement. 5. be willing to provide an end of year report and a letter of thanks to the estate of the donor. 6 . Applicants must have a confirmed place to study the one year LLM Law programme at King's in September. 7. be willing to provide an end of year report and a letter of thanks to the estate of the donor

Level of Study: Postgraduate

Type: Scholarship

Value: $£ 10,000$ will be awarded for European Union students

Frequency: Annual

Country of Study: Any country

Application Procedure: Provided your application form has been accurately completed and the appropriate documentary evidence supplied, you will be notified of the decision during June. 1. The award of a scholarship to an offer-holder will be conditional upon: the offer-holder accepting a place on the King's LLM programme and. 2. the fulfilment by the offerholder of all conditions, both academic and English Language, attached to his or her offer of a place at King's by 10 July

Closing Date: 12 April

Funding: Private

\section{For further information contact:}

Tel: $\quad$ (44) 2078484204

Email: funding@kcl.ac.uk

\section{Santander Masters Scholarship}

Purpose: King's will be offering one scholarship per Faculty to an eligible international student starting a postgraduate taught programme in September. Students may be undertaking study in any discipline

Eligibility: Eligible applicants must meet the following criteria: 1 . At the time of application, be a permanent resident of and ordinarily resident in one of the following Santander Network countries for at least 3 years prior to the start of the programme: Belgium, Italy, France, Germany, Poland, Portugal, Spain and the United Kingdom. 2. Be undertaking a fulltime postgraduate taught Masters degree programme, commencing September. 3. Hold a conditional or unconditional offer of a place on the relevant programme. 4. Have applied to King's no later than 31 March. 5. Fulfil the relevant academic and English Language proficiency requirements set by King's. 6. Complete and submit the necessary scholarship application form and supporting documentation by the stated deadline of 15 May

Level of Study: Postgraduate

Type: Scholarship

Value: $£ 5,000$

Frequency: Annual

Country of Study: Any country

Application Procedure: In order to be considered for an award, candidates must: 1. Submit a complete online admissions application (via apply.kcl.ac.uk/) for a postgraduate Master's programme by 31 March. 2 . Submit the application form by 15 May, 23:59. Note that this application form should only be completed after a complete admissions application has been submitted to the university and a conditional/unconditional place on the programme has been offered

Closing Date: 31 March

Funding: Private

\section{For further information contact:}

King's College London Strand, WC2R 2LS, London, United Kingdom

Email: funding@kcl.ac.uk

\section{STEM Education Teacher Scholarship}

Purpose: The STEM Education Teacher Scholarship is funded by Wipro Limited, a leading global information technology, consulting and business process services company Eligibility: To be considered for a scholarship, on time of application, applicants MUST: 1. Work in a state-funded school in United Kingdom (e.g. comprehensive, academy, free school). Including, primary, secondary and FE-levels. 2. Be a specialist teacher in: Science, Mathematics, Computer Science or Geography. 3. Have completed, or is completing, their NQT year. 4. Have submitted an application for the MA in STEM Education 
Level of Study: Professional development

Type: Scholarship

Value: $70 \%$ of the total fees

Frequency: Annual

Country of Study: Any country

Closing Date: 28 April

Funding: Private

\section{For further information contact:}

King's College London, Strand, WC2R 2LS, London, United Kingdom

Email: funding@kcl.ac.uk

\section{Kingdom of the Netherlands}

\section{Small Scale Support Program and Accountability Fund}

Subjects: The Dutch government has set up a Small Scale Support Program (SSSP) to support projects in countries with which the Netherlands does not have a development cooperation relationship, such as India

Purpose: It support projects in countries with which the Netherlands does not have a development cooperation relationship, such as India

Eligibility: The Embassy receives a large number of project applications whereas the budget available is sufficient to support only a limited number of projects. Check the website link for further communication. ngobox.org/full-grantannoucement_Small-Scale-Support-Program-and-Accountab ility-Fund-2019-Kingdom-of-the-Netherlands 1747

Level of Study: Graduate

Type: Funding support

Frequency: Annual

Country of Study: Any country

Application Procedure: If your organization is working in India and provided that your project complies with the above mentioned criteria and is eligible to apply, please fill in the SSSP form. Organizations from Nepal and Bhutan, and projects in India with a focus on lobbying and advocacy have to use the Accountability form

Closing Date: 31 January

Funding: Private

\section{For further information contact:}

Email: NDE-SMRP@minbuza.nl

\section{Kingston University}

River House, 53-57 High Street, Kingston upon Thames, KT1 1LQ, Surrey, United Kingdom

Tel: $\quad$ (44) 2084179000

Contact: Kingston University

The university's aim is to be internationally recognized for a creative approach to education that has practical outcomes which benefit people and communities. University rated among top $15 \%$ globe in latest QS World University Rankings Kingston University rated among top $15 \%$ globe in latest QS World University Rankings.

\section{Annual Fund Postgraduate Scholarships}

Subjects: Taught masters courses in the Kingston School of Art, Faculty of Business and Social Sciences and Faculty of Science, Engineering and Computing

Purpose: The aim is to encourage academic excellence and allow talented young graduates to continue to higher levels of learning and research, by offering a reduction in course fees for the most academically able applicants

Eligibility: Have already received an offer of a place to study at Kingston on an eligible course. Have first-class honours in a previous degree, or high 2:1 with additional evidence of academic excellence. Assessed as having Home/European Union fee status (not Overseas fee status). Students from outside the United Kingdom need to meet Kingston University's English language requirements - these depend on the course they are applying for

Level of Study: Postgraduate

Type: Scholarship

Value: The scholarship offers a $£ 3,000$ (full time) or $£ 1,500$ (part-time) reduction in annual course fees

Length of Study: Up to 2 years full time or 4 years part time Frequency: Annual

Study Establishment: Kingston University

Country of Study: United Kingdom

No. of awards offered: 60

Application Procedure: Completed application form 1. Academic letters of reference. 2. Copy of academic transcripts. 3. Copies of any certificates relevant to prizes or awards

Closing Date: 12 May

Funding: Individuals

Contributor: Alumni of Kingston University

No. of awards offered last year: 14

No. of awards applicants last year: 60 
Additional Information: For more details, see the website: www.kingston.ac.uk/postgraduate/fees-and-funding/fundingyour-course/scholarships/annual-fund-scholarship/

\section{For further information contact:}

Tel: $\quad$ (44) 2084173299

Email: development@kingston.ac.uk

Contact: Mrs Karen Nowland, Development Administrator

\section{Klynveld Peat Marwick Goerdeler Foundation}

3 Chestnut Ridge Road, Montvale, NJ 07645, United States of America

$\begin{array}{ll}\text { Tel: } & \text { (1) } 2013077932 \\ \text { Fax: } & \text { (1) } 2013077093\end{array}$

Email: acenglish@kpmg.com

Website: www.kpmgfoundation.org

Contact: Anita C. English, Scholarship Administrator

\section{American Institute of Certified Public Accountants Fellowship for Minority Doctoral Students}

Subjects: Accounting

Purpose: The AICPA Fellowship for Minority Doctoral Students ensures that CPAs of diverse backgrounds are visible in college and university classrooms. The program's goal is to increase the number of minority CPAs who serve as role models and mentors to young people in the academic environment and university classrooms

Eligibility: a) Applied to a $\mathrm{PhD}$ program and awaiting word on acceptance; b) been accepted into a $\mathrm{PhD}$ program; or c) already matriculated in a doctoral program and pursuing appropriate coursework; Earned a Master's Degree and/or completed at least 3 years of full-time experience in the accounting practice; 1 . Minority student of Black or African American; Hispanic or Latino; or Native American ethnicity or Alaska Native; Native Hawaiian or Pacific Islander ethnicity. 2. Attend school on a full-time basis and plan to remain enrolled full-time until attaining $\mathrm{PhD}$. 3. Agree not to work full-time in a paid position or accept responsibility for teaching more than one course per semester as a teaching assistant, or dedicate more than one quarter of my time as a research assistant

Level of Study: Doctorate

Type: Scholarship
Value: US $\$ 10,000$ per year, renewable for a total of 5 years Length of Study: Up to 5 years

Frequency: Annual

Study Establishment: A full-time AACSB-accredited university

Country of Study: United States of America

Application Procedure: Applicants must visit the website for further information and application forms

Closing Date: 15 May

Funding: Private

Additional Information: The awards are to be announced in May

\section{For further information contact:}

Email: academics@aicpa.org

\section{Korea Foundation}

Fellowship Programme, 10th Floor, Diplomatic Center Building, 1376-1 Seocho-2-dong, Seocho-gu, Seoul 137-863, Korea

Tel: $\quad$ (82) 234635614

Fax: (82) $234636075 / 6076$

Email: fellow@kf.or.kr

Website: www.kf.or.kr

Contact: Ms Bo Myung KIM, Programme Officer

The Korea Foundation seeks to improve awareness and understanding of Korea worldwide as well as to foster co-operative relationships between Korea and foreign countries through a variety of exchange programmes.

\section{Korea Foundation Fellowship for Field Research}

Subjects: Korea-related research in the humanities and social sciences, culture and arts, and comparative research related to Korea

Purpose: To promote Korean studies and support professional researchers in Korean studies by facilitating their research activities in Korea

Eligibility: Open to university professors and instructors, doctoral candidates, researchers and other professionals. Candidates must be proficient in Korean or English. In the case of Korean nationals, only those with foreign residency status and regular faculty positions at foreign universities are eligible to 
apply. Fellows in this programme must concentrate on their research and may not enrol in any language courses or other university courses during the fellowship period. Candidates who are receiving support from other organizations or programmes administered by the Korea Foundation are not eligible to receive this fellowship at the same time

Level of Study: Doctorate, Postdoctorate, Professional development, Research

Type: Fellowship

Value: The grant amount will be determined by the Foundation according to the Fellow

Length of Study: 3 months-1 year

Frequency: Annual

Country of Study: Korea

No. of awards offered: 75

Application Procedure: Applicants must complete an application form. Application forms are available from the Foundation and the website

Closing Date: 31 July

No. of awards offered last year: 45

No. of awards applicants last year: 75

For further information contact:

Email: hklee@kf.or.kr

\section{Korea Foundation Fellowship for Korean Language Training}

Subjects: Korean studies related to the humanities, culture and arts, social sciences or comparative research

Purpose: To provide foreign scholars and graduate students who need systematic Korean language education with the opportunity to enrol in a Korean language programme at a language institute affiliated to a Korean university

Eligibility: Candidates must have a basic knowledge of, and an ability to communicate in, the Korean language. In the case of Korean nationals, only those with foreign residency status are eligible to apply. Candidates who are receiving support from other organizations or programmes administered by the Korea Foundation are not eligible to receive this fellowship at the same time

Level of Study: Graduate, Postgraduate

Type: Fellowship

Value: The grant amount will be determined by the Foundation according to the Fellow

Length of Study: 6 months, 9 months or 1 year

Frequency: Annual

Study Establishment: A language institute affiliated to a Korean university
Country of Study: Korea

No. of awards offered: 127

Application Procedure: Applicants must complete an application form are available from the Korean Foundation. Applicants must request an application form by supplying their curriculum vitae along with details of their including Korean language ability and previous study of Korean

Closing Date: 31 May

No. of awards offered last year: 92

No. of awards applicants last year: 127

For further information contact:

Email: koreanstudies@isop.ucla.edu

\section{Korea Foundation Postdoctoral Fellowship}

Subjects: Korea-related research in the humanities and social sciences, culture and arts, and comparative research related to Korea

Purpose: To provide promising and highly qualified $\mathrm{PhD}$ recipients with the opportunity to conduct research at leading universities in the field of Korean studies so that they can further develop their scholarship as well as have their dissertations published as manuscripts

Eligibility: Open to non-Korean scholars who have received a PhD degree in a subject related to Korea within 5 years of their application, but do not currently hold a regular faculty position. Korean nationals with permanent resident status in foreign countries may apply. Candidates who are receiving support from other programmes administered by the Korea Foundation are not eligible to receive this fellowship at the same time

Level of Study: Postdoctorate

Type: Fellowship

Value: Stipend support for a 1-year period, of an amount to be determined based on the country, region and institution where the Fellow will conduct his or her research

Length of Study: 1 year

Frequency: Annual

Country of Study: Any country

Application Procedure: You will need to email a separate KI Korea Foundation application by the KI deadline, as well as, complete and submit the Korea Foundation application via the KF online portal by the Korea Foundation deadline. Be sure to verify and confirm the specific KF deadline by visiting the Korea Foundation website: Complete application form must have the following details. For further information, check with the below link. www.kf.or.kr/

Closing Date: 7 January 


\section{For further information contact:}

CGIS South Building, Second Floor, 1730, Cambridge Street, MA 02138, Cambridge, United Kingdom

Tel: (44) $617496-2141$

Email: cglover@fas.harvard.edu

\section{Kosciuszko Foundation}

The Kosciuszko Foundation, Inc., 15 East 65th Street, New York, NY 10065, United States of America

Tel: $\quad$ (1) 2127342130

Fax: (1) 2126284552

Email: addy@thekf.org, info@thekf.org

Website: www.thekf.org

The Kosciuszko Foundation, founded in 1925, is dedicated to promoting educational and cultural relations between the United States of America and Poland and increasing American awareness of Polish culture and history. In addition to its grants and scholarships, which total US $\$ 1,000,000$ annually, the Foundation presents cultural programmes including lectures, concerts and exhibitions, promotes Polish culture in the United States of America and nurtures the spirit of multicultural co-operation.

\section{Jozef Tischner Fellowships}

Subjects: All academic disciplines related to IWM's main research fields

Purpose: To fund a Polish junior researcher in any academic discipline to work in Vienna on research projects of their choice related to one of the Institute for Human Sciences' (IWM) main research fields

Eligibility: Open to Polish citizens, permanent residents of Poland and Polish-American scholars with a recent $\mathrm{PhD}$ degree, not older than 35 years

Level of Study: Doctorate, Research

Type: Fellowship

Value: Fellowship and $€ 8,000$ stipend to cover accommodation, living expenses, travel, health insurance and incidentals during the stay

Length of Study: 6 months

Frequency: Annual

Study Establishment: The Institute for Human Sciences (IWM)
Country of Study: Austria

Application Procedure: Applicants must send the application by mail to address below

Closing Date: 1 December

For further information contact:

Fax: (1) 3135830

Email: fellowships@iwm.at

\section{Polish National Alliance of Brooklyn, United States of America, Inc. Scholarship}

Subjects: Any subject

Purpose: To fund qualified undergraduate students for fulltime studies at accredited colleges and Universities in the United States

Eligibility: Applicant must be a Unites States citizen of Polish descent or Polish citizen with permanent residency status in the United States, a member in good standing of the Polish national alliance of Brooklyn, United States of America, Inc., with a minimum GPA of 3.0

Type: Scholarship

Value: US $\$ 2,000$

Frequency: Annual

Study Establishment: At accredited colleges and universities in the United States

Country of Study: United States of America

Application Procedure: Submit application form, US\$25 non-refundable application fee and supporting materials to the Kosciuszko foundation. E-mailed and faxed materials will not be considered

Closing Date: 14 January

Funding: Private

\section{Krist Law Firm, P.C}

\section{Fax: (44) 2813269197}

Email: scholarship@houstoninjurylawyer.com

\section{The Krist Law Firm, P.C. National Scholarship}

Purpose: Our Houston maritime lawyers are proud to announce that The Krist Law Firm, P.C. will be renewing our annual scholarship of US $\$ 10,000$ to award an individual student the financial resources to accomplish their educational goals and prepare for future career aspirations! 
Eligibility: 1. Be a United States citizen or permanent resident. 2. Be accepted to or currently enrolled in an accredited college, university, or graduate program within the United States. 3. Have a cumulative GPA of 3.0 or higher. 4. Demonstrate good character and high initiative

Level of Study: Graduate

Type: Scholarship

Value: US $\$ 10,000$

Frequency: Annual

Country of Study: United States of America

Closing Date: 31 March

Funding: Foundation

\section{For further information contact:}

Email: scholarship@houstoninjurylawyer.com

\section{Kungliga Tekniska högskolan Royal Institute of Technology}

Stockholm SWE -100 44, Sweden

Tel: $\quad$ (46) 87906000

Contact: KTH Royal Institute of Technology

KTH Royal Institute of Technology is a university in Stockholm, Sweden, specializing in Engineering and Technology, it ranks highest in northern mainland Europe in its academic fields.

\section{Postdoctoral Scholarship in Solar Fuels at KTH}

Subjects: Scholarships are awarded in the field of Solar Fuels Purpose: A postdoctoral scholarship in Solar Fuels is available at the KTH Royal Institute of Technology

Eligibility: Students from Sweden can apply for this scholarship.If English is not your first language then you will need to show that your English language skills are at a high enough level to succeed in your studies

Type: Postdoctoral fellowship

Value: 25,000 per month

Country of Study: Sweden

Application Procedure: Apply for this scholarship by e-mail Closing Date: 26 February

Funding: Private

Additional Information: For more details please contact the website scholarship-positions.com/postdoctoral-scholarshipsolar-fuels-kth-sweden/2018/02/19/

\section{For further information contact:}

Email: lichengs@kth.se

\section{Kurt Weill Foundation for Music}

7 East 20th Street, New York, NY 10003, United States of America

Tel: $\quad$ (1) 2125055240

Fax: $\quad$ (1) 2123539663

Email: kwfinfo@kwf.org

Website: www.kwf.org

Contact: Ms Elizabeth Blaufox, Assoc. Director of Programs

The Kurt Weill Foundation for Music is a non-profit, private foundation chartered to preserve and perpetuate the legacies of the composer Kurt Weill (1900-1950) and his wife, singer and actress Lotte Lenya (1898-1981). The Foundation awards grants and prizes, sponsors print and online publications, maintains the Weill-Lenya Research Center and administers Weill's copyrights.

\section{Kurt Weill Prize}

Subjects: Encourages distinguished scholarship in the disciplines of Music, Theater, Dance, Literary criticism and history addressing music theater since 1900 (including Opera). Two prizes are awarded bi-annually: US $\$ 5,000$ to the author of the winning book entry; and a prize of US\$2,000 to the author of the winning article entry

Purpose: To encourage distinguished scholarship in the disciplines of music, theater, dance, literary criticism and history addressing music theater since 1900 (including opera)

Eligibility: Open to nationals of any country

Level of Study: Unrestricted

Type: Prize

Value: US $\$ 5,000$ for books, US $\$ 2,000$ for articles

Frequency: Every 2 years

Country of Study: Any country

Application Procedure: Applicants must submit five copies of their published work. Works must have been published within the 2 years preceding the award year. Please visit www. kwf.org for additional information

Closing Date: 30 April

Funding: Private

\section{For further information contact:}

Email: bsansone@kwf.org 